\title{
The role of self-efficacy, emotional intelligence and leadership style as attributes of leadership effectiveness
}

\begin{tabular}{|c|c|}
\hline \multicolumn{2}{|c|}{$\begin{array}{l}\text { Authors: } \\
\text { Yvette Ramchunder } \\
\text { Nico Martins }{ }^{1}\end{array}$} \\
\hline \multicolumn{2}{|c|}{$\begin{array}{l}\text { Affiliations: } \\
{ }^{1} \text { Department of Industrial } \\
\text { and Organisational } \\
\text { Psychology, University of } \\
\text { South Africa, South Africa }\end{array}$} \\
\hline \multicolumn{2}{|c|}{$\begin{array}{l}\text { Correspondence to: } \\
\text { Nico Martins }\end{array}$} \\
\hline \multicolumn{2}{|c|}{$\begin{array}{l}\text { Email: } \\
\text { martin@unisa.ac.za }\end{array}$} \\
\hline \multicolumn{2}{|c|}{$\begin{array}{l}\text { Postal address: } \\
\text { PO Box 392, Universi } \\
\text { South Africa 0003, } \\
\text { South Africa }\end{array}$} \\
\hline \multicolumn{2}{|c|}{$\begin{array}{l}\text { Dates: } \\
\text { Received: } 27 \text { Feb. } 2013 \\
\text { Accepted: } 04 \text { Mar. } 2014 \\
\text { Published: } 23 \text { May } 2014\end{array}$} \\
\hline \multicolumn{2}{|c|}{$\begin{array}{l}\text { How to cite this article: } \\
\text { Ramchunder, Y., \& Martins, } \\
\text { N. (2014). The role of } \\
\text { self-efficacy, emotional } \\
\text { intelligence and leadership } \\
\text { style as attributes of } \\
\text { leadership effectiveness. } \\
\text { SA Journal of Industrial } \\
\text { Psychology/SA Tydskrif vir } \\
\text { Bedryfsielkunde, } 40(1) \text {, Art. } \\
\text { \#1100, } 11 \text { pages. http:// } \\
\text { dx.doi.org/10.4102/sajip. } \\
\text { v40i1.1100 }\end{array}$} \\
\hline \multicolumn{2}{|c|}{$\begin{array}{l}\text { Copyright: } \\
\text { (C) 2014. The Authors. } \\
\text { Licensee: AOSIS } \\
\text { OpenJournals. This work } \\
\text { is licensed under the } \\
\text { Creative Commons } \\
\text { Attribution License. }\end{array}$} \\
\hline \multicolumn{2}{|l|}{ Read online: } \\
\hline 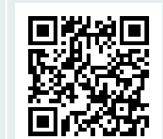 & $\begin{array}{l}\text { Scan this QR } \\
\text { code with your } \\
\text { smart phone or } \\
\text { mobile device } \\
\text { to read online. }\end{array}$ \\
\hline
\end{tabular}

Orientation: Researching the impact of psychological constructs on police leadership may add value when appointing people in leadership positions or developing people for leadership roles in the police environment.

Research purpose: The purpose of this study is to explore the relationship between three constructs, namely emotional intelligence, self-efficacy and leadership effectiveness in a policing context.

Motivation for this study: In the police sector, there are difficulties in linking leadership to organisational outcomes since common police-leadership measures are affected by multiple contributory factors. This study explores the psychological constructs of emotional intelligence and self-efficacy on the leadership effectiveness of the police.

Research design, approach and method: This research adopted a quantitative approach to assess the relationship between emotional intelligence and self-efficacy as attributes of leadership effectiveness. A total of 107 police personnel in commanding positions made up the sample. The measuring instruments used were the Assessing Emotions Scale, the Self-efficacy Scale and the Multifactor Leadership Questionnaire (MLQ Form 5X).

Main findings: The results confirmed a positive relationship between emotional intelligence and self-efficacy and leadership effectiveness. The correlations were significant at the 0.01 level (2-tailed).

Practical/managerial implications: Emotional intelligence and self-efficacy should be considered as attributes during the selection of leaders in police organisations or used for developmental purposes to enhance these attributes in police leaders.

Contribution/value-add: The insights gained from the findings may be used to guide the selection of future leaders in the policing environment, and they could also be used to establish future developmental programmes and research initiatives.

\section{Introduction}

\section{Key focus of the study}

Since its transition to democracy, South Africa has gained a reputation as a dangerous country because it has one of the highest rates of crime in the world (Mattes, 2006). South Africa faces diverse challenges in the policing environment. The police service is complex in its organisational structure and also faces difficult leadership challenges. The statement by Clark (2005), ' $\ldots$ that leaders in a complex organisation, have to meet the challenges of a society that is diverse, pragmatic and questioning of authoritative stances', is also applicable to police organisations in South Africa. Competent management is one source of sustainable competitive advantage in contemporary, rapidly changing organisations (Gilley, McMillan \& Gilley, 2009). Leadership, or its absence, is recognised as a key force shaping outputs and outcomes in most formal or informal organisations (Schafer, 2008).

The task of the police leaders includes the implementation of policy to guide crime-prevention activities, create societal consensus on crime prevention, develop and implement national programmes to address the causes of crime, mobilise community resources and engage communities in all crime-prevention activities (Artz \& Oliveira, 1998, cited in Adam, 2010). The multidimensional increase in complexities from organisational structures to societal demands may render leaders ineffective if they are unable to adjust to these complexities. One can ask whether this ability to adjust to the complexities is innate and, for the purpose of this research, whether a leader's effectiveness is associated with the psychological constructs of emotional intelligence and self-efficacy. According to Hughes, Ginnett and Curphy (2006), leadership involves both the rational and emotional sides of human experience. Riggio, Murphy and Pirozzolo (2002) propose 
that effective leaders possess multiple forms of intelligence which allow them to respond successfully to a range of situations.

\section{Background to the study}

Police organisations have their own structural and cultural milieu that informs facets in these organisations, in particular their leadership. According to Schafer (2008, p. 239), 'the absence of quality leaders in policing is, in part, due to a common failure to develop officers to become more effective leaders'. Rapid change requires an organisation to have employees and leaders who are adaptable, work effectively, constantly improve systems and processes, are customer focused and share the need to make a profit (Weinberger, 2004). In the case of the South African Police Service (SAPS), the leaders are responsible for effectively managing good order, the control and discipline of all members under their command and keeping the community safe. The rapid changes that leaders in the SAPS face are systemic. Lewis, Goodman and Fandt (1998) assert that managers of the future will have to be prepared to cope with change if they are to be effective. As with other organisations today, the SAPS is experiencing diverse challenges in its internal and external operational environment that could have an impact on leadership in the organisation. As proposed by Riggio et al. (2002), organisational effectiveness depends on leadership effectiveness. However, according to a study by Campbell and Kodz (2011), the difficulties of linking leadership with organisational outcomes are particularly pronounced for the police since common performance measures in the police are affected by multiple confounding factors.

\section{Trends from literature}

In reviewing emotional-intelligence research, Higgs and Dulewics (1999) and Cavazotte, Moreno and Hickmann (2012) indicate that a view is developing that emotional intelligence may be strongly related to leadership. Exactly how and to what extent emotional intelligence accounts for effective leadership is unknown (Palmer, Walls, Burgess \& Stough 2001). However, scholars have also focused on relating emotional intelligence to leadership (George, 2000) or showing how components of emotional intelligence such as empathy are important traits that contribute to leadership (Kellett, Humphrey \& Sleeth, 2002; Wolff, Pescosolido \& Druskat, 2002).

A study by Coetzee and Schaap (2005) indicates a significant correlation between the emotional intelligence scores and the effective and ineffective leadership scores $(r=0.342 ; p<0.01)$ of their sample group. Effective leadership was significantly positively related $(t=2.359 ; p<0.05)$ to emotional intelligence, and ineffective leadership was significantly negatively related $(t=-2.645 ; p<0.01)$ to emotional intelligence. Thus, Coetzee and Schaap (2005) conclude that a significant relationship does exist between emotional intelligence and what can be considered as effective and ineffective leadership. The research reported in this article is similar to that of Coetzee and Schaap (2005) in that one of the hypotheses looks at the relationship between emotional intelligence and leadership effectiveness. Limited research has been conducted to determine the relationship between self-efficacy and emotional intelligence as attributes for effective leadership in the policing environment and in the South Africa context in particular.

\section{Research objectives}

The purpose of this research was to determine the relationship between emotional intelligence and self-efficacy as attributes and the extent (if any) to which they influence leadership effectiveness.

\section{The potential value added by the study}

The findings of this research may provide useful insights into the psychological constructs of emotional intelligence and self-efficacy, which may (or may not) influence leadership effectiveness in the police. The insights gained from these findings may be used to guide selection processes for future leaders in the policing environment, and these insights could also be used to establish future developmental programmes and research initiatives.

\section{What will follow?}

In the next section, the literature review relating to leadership is discussed, followed by the research design for the quantitative study conducted amongst police employees. Based on the findings, the conclusion and recommendations for future initiatives are presented. A statistical analysis of the results is then presented and the findings discussed. A synopsis of the most significant information will form the conclusion, the limitations of this research will be highlighted and recommendations will be made for future initiatives.

\section{Literature review}

Various leadership-related concepts are relevant to this study. In this review, leadership effectiveness, emotional intelligence and the relationship between self-efficacy, emotional intelligence and leadership style warrant further discussion.

\section{Leadership effectiveness}

Leadership effectiveness stems from the concept of leadership, which, over several decades, has accumulated many different definitions. According to Hogan, Curphy and Hogan (1994), leadership involves persuading other people to set aside, for a period of time, their individual concerns and to pursue a common goal that is important for the responsibilities and welfare of the group. Leadership is the process of communication (verbal and non-verbal) that involves coaching, motivating or inspiring, directing or guiding and supporting or counselling others (Howard, 2005). Heifetz and Linsky (2004) highlight leadership as the ability to influence and mobilise individuals identified with specific skills to discuss and complete specific tasks in order 
to achieve results. This definition highlights the human component in leadership. Dorbrzanska (2005) further mentions the human element as being key to such relations since leadership is seen as the ability to express and channel human autonomy.

Leadership effectiveness, according to Barnard (1968, cited in Hollander, 1978, p. 112), is the accomplishment of the recognised objectives of cooperative action, which initially depends on influence. Beyond that, however, there are questions of value such as how things are done to achieve the objective. Leadership effectiveness differs in terms of understanding in that a particular context will require a particular kind of leader's effectiveness applied to a particular situation. One major distinction between definitions of leadership effectiveness is the type of consequences or outcome selected to be the effectiveness criterion (Yukl, 1981). Although effective leadership is a desired commodity, in policing, limited scholarly attention has been given to studying the leadership process and the barriers to developing more efficacious leadership practices (Schafer, 2008).

Good leadership is more than only performing calculations and planning or following a checklist, and even though rational analysis can enhance effective leadership, good leadership also involves touching the feelings of others, and emotions play a key role in leadership too (Hughes, Ginnett \& Curphy, 2006). Leadership is intrinsically an emotional process whereby leaders recognise followers' emotional states, attempt to evoke emotions in followers and then seek to manage followers' emotional states accordingly (Humphrey, 2002).

\section{The role of emotional intelligence in effective leadership}

Given the increased recognition of the importance of emotions in leadership literature, the question has arisen whether the concept of emotional intelligence, measured as a set of abilities, might provide insight into the difference between outstanding and below-par levels of leadership performance (Herbst \& Maree, 2008). According to Mayer, Salovey and Caruso (2000), emotional intelligence includes the ability to perceive, appraise and express emotions accurately and adaptively; the ability to understand emotion and emotional knowledge; the ability to access and generate feelings where they facilitate cognitive activities and adaptive action and the ability to regulate emotions in yourself and others. Goleman (1998) defines emotional intelligence as the capacity for recognising your own feelings and those of others, for motivating yourself and for managing your own emotions and your relationships well. The ability to identify emotions allows leaders to be aware of their own feelings and emotions. This ability also allows the leader to accurately identify the emotions of the group and of the individual followers to express emotion accurately and to differentiate between honest and phoney emotional expressions (Riggio et al., 2002). George (2000) suggests that emotional intelligence plays a vital role in leadership effectiveness and can promote effectiveness at all levels in organisations. This leads to the first hypothesis:

Hypothesis 1: There is a positive relationship between emotional intelligence and effective leadership.

The relationship between self-efficacy, emotional intelligence and leadership style: Leadership is a process of social interaction where the leader's ability to influence the behaviour of followers can strongly influence performance outcomes (Humphrey, 2002). According to Palis and Green (2002), self-efficacy is an estimate of one's ability to orchestrate performance by successfully executing the behaviour that are required to produce desired outcomes. Eden (1988) argues that leadership is the mechanism through which managers raise performance expectations and enhance self-efficacy, which, in turn, increases performance. Self-efficacy is defined as the beliefs in one's capabilities to organise and execute the course of action required to produce certain attainments (Bandura, 1982, cited in Villanueva \& Sanchez, 2007, p. 350). Bandura (1986) states that self-efficacy is the chief construct that links ability to performance. The higher the self-efficacy people feel, the more confident they will feel about successfully completing a task (Villanueva \& Sanchez, 2007). According to Riggio et al. (2002), high self-efficacy has been shown to lead to increased performance in a wide range of situations.

Researchers such as Chuang, Judge and Liaw (2012) have found a relationship between transformational leadership and the efficacy of organisations. Leadership represents a crucial determinant of organisational efficacy in the police (Adam, 2010). Moving towards domains of leadership, however, requires police organisations to formulate definitions of what effective leadership means in their own communities and policing contexts (Schafer, 2008).

Investigating the link between emotional intelligence and leadership style, Palmer et al. (2001) administered a self-report emotional intelligence measure to 43 managers to evaluate the link between emotional intelligence and leadership style. They found significant correlations with several components of the transformational leadership model. In particular, the inspirational-motivation and individualised-consideration components of transformational leadership correlated with the ability to monitor emotions and the ability to manage emotions (De Miranda, 2011). Inspirational motivation was moderately correlated with both the emotional-monitoring $(r=0.42 ; p<0.01)$ and emotional-management $(r=0.37$; $p<0.05)$ scales. Similarly, individual consideration also correlated with the emotional monitoring and management $(r=0.55 ; p<0.01 ; r=0.35 ; p<0.05)$ (Palmer et al., 2001).

Similarly, Barling, Slater and Kelloway (2000) conducted an exploratory study on the relationship between emotional intelligence and transformational leadership. Their results suggest that emotional intelligence is associated with three aspects of transformational leadership, namely idealised influence, inspirational motivation and individualised 
consideration. The leaders who report exhibiting these kinds of behaviour were assumed to be more effective in the workplace (De Miranda, 2011). In recent years, the notion of emotional intelligence has been deemed to be critically important for effective leadership (Bipath, 2007).

Theoretically, the area of emotional intelligence appears to have great validity as indicated in studies by Barling et al. (2000), Palmer et al. (2001) and Coetzee and Schaap (2005). These studies provide empirical justification for the relationship between emotional intelligence and effective leadership. In a recent research study in a South-African petrochemical organisation, Pillay, Viviers and Mayer (2013) found significant positive relationships between emotional intelligence and transformational leadership.

Research on self-efficacy and leadership effectiveness is limited in this field. However, there is research on different kinds of self-efficacy such as leader self-efficacy and task selfefficacy. More recently, researchers have shown interest in the more trait-like generality dimension of self-efficacy, which has been termed general self-efficacy (GSE) (Eden, 1988; Gardner \& Pierce, 1998; Judge, Locke, Durham \& Kluger, 1998. The following two hypotheses are derived from the discussion:

Hypothesis 2: There is a positive relationship between self-efficacy and effective leadership.

Hypothesis 3: There is a positive relationship between emotional intelligence and self-efficacy.

It is evident after conducting an extensive literature research that more research should be done in the South-African context and more specifically in the police context. Furthermore, research into the relationship between self-efficacy and leadership effectiveness and emotional intelligence should be conducted in order to increase knowledge in the field.

\section{Research design}

\section{Research approach}

A quantitative design was used to achieve the research objectives, which involved using questionnaires to gather data in a representative sample of the police in the KwaZuluNatal (South Africa) population. The sample that the research targeted was all those employees in commanding positions in an Essential Services Department of the SAPS. The type of sampling method used was the convenience sampling, which involves choosing a sample according to availability to the researcher (Leedy and Ormond, 2005, cited in Hayward, 2005). Spearman's rho was used to determine the relationships between emotional intelligence, self-efficacy and leadership effectiveness.

\section{Research method}

\section{Research participants}

In total, 107 employees from Essential Services Departments responded. Table 1 provides an overview of the biographical information of the respondents who participated.
TABLE 1: Biographical and demographical characteristics of respondents.

\begin{tabular}{llll}
\hline Variable & Category & $f$ & $\%$ \\
\hline Gender $(n=107)$ & Female & 23 & 21.5 \\
Age $(n=105)$ & Male & 84 & 78.5 \\
& Age 18-29 & 1 & 1.0 \\
& Age 30-39 & 5 & 4.7 \\
& Age 40-49 & 67 & 63.8 \\
& Age 50-59 & 32 & 30.5 \\
Marital status $(n=102)$ & Divorced & 9 & 8.8 \\
& Married & 84 & 82.4 \\
& Single & 8 & 7.8 \\
Do you work weekends? $(n=102)$ & Widowed & 1 & 1.0 \\
Home language $(n=104)$ & Yes & 43 & 42.2 \\
& No & 59 & 57.8 \\
Level of employment $(n=104)$ & African languages & 51 & 49.0 \\
& English or Afrikaans & 53 & 51.0 \\
& Junior management & 50 & 48.1 \\
& Middle management & 31 & 29.8 \\
\hline
\end{tabular}

$f$, frequency.

The sample comprised $78.5 \%$ male and $21.5 \%$ female respondents. The largest age category $(63.8 \%)$ is between 40 and 49 , followed by $30.5 \%$ in the age group of $50-59$. The variable on marital status showed a response of 102 out of 107 participants. Of these respondents, $8.8 \%$ were divorced, $82.4 \%$ were married and $7.8 \%$ were single. For the variable, 'Do you work weekends?', 43 of the 102 respondents replied 'Yes', which represents $42.2 \%$ of respondents. The home language variable indicated that $49 \%$ spoke an African language, and $51 \%$ spoke English or Afrikaans. For the last variable, 'Level of employment', $48.1 \%$ of the respondents were in junior management, $29.8 \%$ in middle management and $22.1 \%$ in senior management. It should be noted that, even though 107 participants participated in this research, not all the participants responded to all questions asked. This is indicated in Table 1 under the variable heading where the sample $(n)$ varies between 102 and 107 in terms of responses to those questions.

\section{Measuring instruments}

Multifactor leadership questionnaire (MLQ 5X): The multifactor leadership questionnaire, also known as the MLQ, assesses a full range of leadership behaviour. The MLQ has proven to be a strong predictor of leader performance across a broad range for organisations (Bass \& Avolio, 1994). The MLQ (5X) has 45 items and uses a five-point Likert scale to measure leadership behaviour. It also has 12 subscales that measure leadership behaviour, namely idealised influence (attributes), idealised influence (behaviour), inspirational motivation, intellectual stimulation, individualised consideration, constructive transaction, management by exception (active), management by exception (passive), laissez-faire, extra effort, effectiveness and satisfaction.

According to Hanke (1998, cited in Coetzee \& Schaap, 2005), the alpha reliability coefficients for the $M L Q$ scales vary between 0.71 and 0.93 . Similar reliabilities were reported by Ackermann, Scheepers, Lessing and Dannhauser (2000, cited 
in Coetzee \& Schaap, 2005) on the $M L Q$ in the South African context and ranged from 0.74 to 0.94 . Pillay et al. (2013) found reliabilities between 0.61 and 0.93 in their study.

Assessing Emotions Scale (AES): The AES is a 33-item, self-report inventory, which uses a five-point Likert scale to measure individuals' emotional intelligence traits. It consists of four subscales: perception of emotion (10 items), managing own emotions (9 items), managing others' emotions ( 8 items) and utilisation of emotions (6 items) (Coetzee \& Beukes, 2010). In terms of reliability (internal consistency), the Cronbach alpha coefficients are 0.55 (moderate) to 0.78 (high). Testretest reliability tests indicate a coefficient score of 0.78 for total scale scores (Coetzee \& Beukes, 2010). Validity studies confirm both the convergent and divergent validity of the AES (Coetzee \& Beukes, 2010). Since the AES has not been standardised for South African populations, scale reliability tests were conducted for the sample group. In the study by Coetzee and Beukes (2010), the internal consistency coefficients obtained for each subscale were only moderate: perception of emotion (0.65), managing own emotions (0.56), managing others' emotions (0.58) and utilisation of emotions (0.54).

Self-efficacy Scale: Self-efficacy was measured by using the Self-efficacy Scale (SES) (Sherer et al., 1982). The SES consists of 27 items. The statements deal with attitudes and feelings that people might have concerning themselves and their performance in a variety of tasks. Each item is answered on a seven-point Likert-type scale varying between one (1) 'strongly agree' and seven (7) 'strongly disagree' whilst four (4) indicates a midpoint. Low scores indicate a high level of self-efficacy (Marais, 1997). Cronbach's alpha coefficients (internal consistency reliability) vary between 0.71 and 0.86. The overall Cronbach alpha coefficient for the scale (as obtained for the sample of the current study) was 0.79 . Research in South Africa confirms the construct and criterion validity of the scale (Marais, 1997; Oosthuizen, 1998).

\section{Research procedure}

The questionnaire booklet designed for this study consisted of the three measuring instruments, the multifactor leadership questionnaire, Assessing Emotions Scale and the Selfefficacy Scale. The questionnaire booklets were accompanied by a cover letter and a permission letter to conduct the research. Permission was obtained from the national office of the Essential Services Department. Confidentiality was guaranteed for all participants. Data was collected in two ways. Some data was collected when the questionnaire booklets were administrated to groups of participants. The purpose of these sessions was to assist any participant who might experience language or other terminology problems. These sessions lasted between 30 and 45 minutes. Other data was collected by certain participants preferring to take the questionnaire booklet and return it to the Cluster Office once they had completed it. Data was collected over a period of eight months. Although two hundred and fifty (250) questionnaires were distributed, only 107 were completed.
Once the questionnaires had been collected, the researcher coded them, and the scores were captured on a Microsoft Excel $^{\circledR}$ spreadsheet and imported into SPSS to be analysed statistically. It should be noted that reverse codes for the Assessing Emotions Scale were items 5, 28 and 33, and for the Self-efficacy Scale, items 1, 2, 9, 10, 12, 22, 25 and 26. When an item is reverse coded, the response to an item is reversed. The self-efficacy scale was originally rated from 'strongly agree' to 'strongly disagree'. This was rescaled from 'strongly disagree' to 'strongly agree.' The reason for the rescale is to allow for the interpretation of the correlation coefficient. The scores were computed on the basis of the full scale of each construct, summed across each item, and the score was then converted to a percentage.

\section{Statistical analysis}

Statistical analysis of the data was conducted using the SPSS statistical package, version 19. Descriptive statistics and inferential statistics were calculated. The descriptive statistics are intended to present a snapshot of the data, and Spearman's rho was used to evaluate the relationships between emotional intelligence, self-efficacy and leadership effectiveness. Owing to the deviation from normality, non-parametric correlation analysis was used to test the hypotheses. This is discussed in detail in the results section. According to Pett (1997), some of the best-known characteristics of nonparametric tests are that:

- Few assumptions are made about the population's distribution

- The scale of measurement of the dependent variable is either categorical or ordinal

- The primary focus is either on rank ordering or frequency of data

- Hypotheses are often formulated in relation to ranks, medians or frequencies of data whilst sample-size requirements are less stringent than for parametric tests.

Some of the disadvantages of using non-parametric methods are that these methods may lack power compared with the more traditional approaches. This is a particular concern if the sample size is small or if the assumptions for the corresponding parametric method (e.g. normality of the data) hold (Furlong, Lovelace \& Lovelace, 2000). Nonparametric methods are geared towards hypothesis testing rather than the estimation of effects, which was the case in this research.

\section{Results}

The first part of the results presents the descriptive statistics for each of the three constructs used in the study whilst the second part reports on the associated inferential statistics.

\section{Descriptive statistics \\ Descriptive and reliability analysis}

Table 2 presents the summary statistics for each construct. The emotional intelligence construct had a mean of 81.35 , a median of 82.42 and a standard deviation of 8.97. Cronbach's 
alpha, which is a measure of the reliability of a scale, was 0.86, which, according to Field (2009), is indicative of a reliable scale.

In Table 2, the self-efficacy construct had a mean of 74.80, a median of 75.13 and a standard deviation of 10.70. Cronbach's alpha for the self-efficacy scale was at an acceptable level of reliability of 0.83 . The leadership (MLQ) had a mean of 65.97, a median of 68.33 , a standard deviation of 11.34 and a Cronbach alpha of 0.88 . Based on the alpha values, the self-efficacy and MLQ scales can be considered to be reliable. As indicated in Table 2, the participants scored, on average, highest on the emotional-intelligence construct, and the median of 82.42 means that $50 \%$ of the sample scored above 82.42. Also, the standard deviation of 8.97 suggests less variability in the participants' scores for this construct compared to the standard deviation of the other two constructs.

Reliability statistics for subscales of the Assessing Emotions Scale and MLQ: The Assessing Emotions Scale indicated $\alpha=0.86$ on the full scale, and the subscale was between $\alpha=0.67$ and $\alpha=0.74$, which is lower than the fullscale alpha reliability. The Assessing Emotions Scale has four subscales: perception of emotions, managing own emotions, managing others' emotions and utilising emotions. Based on the Cronbach alpha, the Assessing Emotions subscales were reliable. The Cronbach alphas were as follows: perception of emotions: $\alpha=0.73$, managing own emotions: $\alpha=0.72$, managing others' emotions: $\alpha=0.67$ and utilising emotions: $\alpha=0.74$ (see Table 3 and Table 4).

The alpha reliabilities of the MLQ were at an acceptable level on the full scale, $\alpha=0.88$, and slightly lower in the subscales ranging from reliability alphas between $\alpha=0.46$ and $\alpha=0.793$. The MLQ has 12 subscales. Table 4 reflects the reliability statistics for the MLQ subscales.

The following subscales were reliable according to the Cronbach alphas: idealised influence (attributes): $\alpha=0.79$, idealised influence (behaviour): $\alpha=0.74$, inspirational motivation: $\alpha=0.69$, individual consideration: $\alpha=0.604$, constructive transaction: $\alpha=0.70$, effort: $\alpha=0.62$ and effectiveness: $\alpha=0.70$. However, there were other subscales that indicated non-reliability, namely intellectual simulation: $\alpha=0.53$, management by exception (active): $\alpha=0.56$, management by exception (passive): $\alpha=0.48$, laissez-faire: $\alpha=0.55$ and satisfaction: $\alpha=0.46$.

Although it depends on what is being measured, according to Terre Blanche, Durrheim \& Painter (2006), a rule of thumb of 0.75 is set as an acceptable level for the Cronbach alpha. The low alpha coefficient of the subscales limits the possibility of generalising the findings. The alpha reliabilities of the MLQ were at an acceptable level on the full scale, $\alpha=0.88$, and slightly lower in the subscales ranging from reliability alphas between $\alpha=0.46$ and $\alpha=0.79$. The self-efficacy scale indicated an alpha reliability at $\alpha=0.83$ as indicated in Table 2 . There were no subscales on the self-efficacy scale.
TABLE 2: Summary of descriptive statistics for each construct.

\begin{tabular}{lccc}
\hline Statistics & \multicolumn{3}{c}{ Constructs } \\
\cline { 2 - 4 } & $\begin{array}{c}\text { Emotional } \\
\text { intelligence }\end{array}$ & Self-efficacy & Leadership (MLQ) \\
\hline M & 81.35 & 74.80 & 65.97 \\
Median & 82.42 & 75.13 & 68.33 \\
SD & 8.97 & 10.70 & 11.34 \\
Cronbach's alpha & 0.86 & 0.83 & 0.88 \\
\hline
\end{tabular}

M, mean; SD, standard deviation; MLQ, Multifactor Leadership Questionnaire.

TABLE 3: Reliability statistics for the emotional intelligence subscales.

\begin{tabular}{lccc}
\hline Subscale & $\begin{array}{l}\text { Number of } \\
\text { items }\end{array}$ & \multicolumn{2}{c}{ Reliability statistics } \\
\cline { 3 - 4 } & & Cronbach's alpha & $\begin{array}{c}\text { Guttmansplit half } \\
\text { coefficient }\end{array}$ \\
\hline $\begin{array}{l}\text { Perception of } \\
\text { emotions (PE) }\end{array}$ & 10 & 0.73 & 0.78 \\
$\begin{array}{l}\text { Managing own } \\
\text { emotions (MOWNE) }\end{array}$ & 9 & 0.72 & 0.71 \\
$\begin{array}{l}\text { Managing others' } \\
\text { emotions (MOE) }\end{array}$ & 8 & 0.67 & 0.71 \\
\begin{tabular}{l} 
Utilising emotions \\
\hline
\end{tabular} & 6 & 0.74 & 0.62 \\
\hline
\end{tabular}

TABLE 4: Reliability statistics for the MLQ subscales.

\begin{tabular}{llcc}
\hline Subscale & $\begin{array}{l}\text { Number of } \\
\text { items }\end{array}$ & $\begin{array}{c}\text { Reliability statistics } \\
\text { (Cronbach's alpha) }\end{array}$ & $\begin{array}{c}\text { Guttmansplit half } \\
\text { coefficient }\end{array}$ \\
\hline $\begin{array}{l}\text { Idealised influence } \\
\text { (attributes) }\end{array}$ & 4 & .79 & .73 \\
$\begin{array}{l}\text { Idealised influence } \\
\text { (behaviour) }\end{array}$ & 4 & .74 & .75 \\
$\begin{array}{l}\text { Inspirational } \\
\text { motivation }\end{array}$ & 4 & .69 & .68 \\
$\begin{array}{l}\text { Intellectual } \\
\text { stimulation }\end{array}$ & 4 & $* .53$ & $* .49$ \\
$\begin{array}{l}\text { Individualised } \\
\text { consideration }\end{array}$ & 4 & .60 & .63 \\
$\begin{array}{l}\text { Constructive } \\
\text { transaction }\end{array}$ & 4 & .70 & .66 \\
$\begin{array}{l}\text { Management by } \\
\text { exception (active) }\end{array}$ & 4 & $* .56$ & $* .53$ \\
$\begin{array}{l}\text { Management by } \\
\text { exception (passive) }\end{array}$ & 4 & $* .48$ & $* .51$ \\
$\begin{array}{l}\text { Laissez-faire } \\
\text { Extra effort }\end{array}$ & 4 & $* .55$ & $* .58$ \\
$\begin{array}{l}\text { Effectiveness } \\
\text { Satisfaction }\end{array}$ & 3 & .62 & .60 \\
\hline
\end{tabular}

*, non-reliable subscale.

Inferential statistics relating to constructs and subscales: The Shapiro-Wilks test of normality revealed that there were significant deviations from normality in the data with respect to the leadership and self-efficacy constructs. This is summarised in Table 5.

Owing to the deviation from normality, a non-parametric correlation analysis was used to test the hypotheses.

The next step of the data analysis looked at the correlations between the three constructs, namely emotional intelligence, self-efficacy and leadership. The correlations in the range 0.3 to 0.5 can be regarded as moderate whilst the correlations in the range 0.1 to 0.3 are modest (Cohen, Manion \& Morrison, 2007). Table 6 reflects the correlation coefficients of this study. As indicated in this table, emotional intelligence was moderately correlated with leadership (Spearman's rho $=0.492 ; p$-value $<0.01$ ) and self-efficacy (Spearman's rho $=0.363 ; p$-value $<0.01)$. Leadership and self-efficacy were moderately correlated (Spearman's rho $=0.342 ; p$-value 
$<0.01$ ). Hence all three of the null hypotheses above were rejected in favour of the corresponding alternate hypotheses.

The variables listed in Table 7 represent the participants' scores on the subscales of the emotional-intelligence and leadership constructs. The scores were calculated by summing across the items making up the subscales. This table includes the variables representing the participants' scores on the selfefficacy, leadership and emotional-intelligence constructs.

Table 7 tests whether or not each variable is normally distributed. The Shapiro-Wilk test shows that all variables, except emotions subscale 1 and emotional intelligence whose p-values are greater than 0.05 , were not normally distributed ( $p$-value $<0.05$ ). This implies that a non-parametric correlation coefficient must be used - hence the use of Spearman's rho in the correlation-analysis table listed below.

Table 8 provides a detailed analysis of this research by focusing on the correlations between the subscales of the instruments used in the study.

For the purpose of analysing Table 8, it should be noted that the leadership subscales can be further grouped into transformational leadership (which includes idealised influence active and passive, inspirational motivation, intellectual stimulation and individual consideration), transactional leadership (which includes constructive transaction, management by exception passive and active) and laissez-faire. There are also three outcomes on the MLQ, which are extra effort, effectiveness and satisfaction. Although leadership styles were not used in this research study, it helps to make certain deductions about the relationship between the subscales. Eagly, Schmidt and Van Engen (2003) report that successful leaders use transformational leadership behaviour more often than transactional or laissez-faire leadership.

The leadership subscale, intellectual stimulation, had the highest correlation with the perceptions of emotions subscale $(r=.399 ; p<0.01)$; this is a moderate correlation. The rest of the leadership subscales, except management by exception (passive) and satisfaction, indicated a significant and moderate relationship with perceptions of emotion (see Table 7).

However, the laissez-faire and management by exception (passive) subscales had a negative correlation with the perceptions of emotion subscale. Correlation coefficients between 0.1 and 0.3 in absolute value are regarded as modest whilst the correlations between 0.3 and 0.5 in absolute value are regarded as moderate (Cohen et al., 2007).

Inspirational motivation was moderately correlated with managing own emotions $(r=0.468 ; p<0.01)$. The management by exception (passive) and laissez-faire subscales were negatively correlated with the managing-ownemotions subscale $(p>0.05)$. All other leadership subscales were significantly correlated with managing own emotions.
TABLE 5: Shapiro-Wilk's test of normality for constructs.

\begin{tabular}{llll}
\hline Construct & $\begin{array}{l}\text { Shapiro-Wilk } \\
\text { statistics }\end{array}$ & $d f$ & $p$-value \\
\hline Emotional intelligence & 0.98 & 107 & 0.13 \\
Leadership & 0.96 & 107 & 0.00 \\
Self-efficacy & 0.92 & 107 & 0.00 \\
\hline
\end{tabular}

$d f$, degrees of freedom.

TABLE 6: Non-parametric correlations using Spearman's rho.

\begin{tabular}{lllll}
\hline Construct & $\begin{array}{l}\text { Correlation } \\
\text { applications }\end{array}$ & $\begin{array}{l}\text { Emotional } \\
\text { intelligence }\end{array}$ & Leadership & Self- efficacy \\
\hline $\begin{array}{l}\text { Emotional } \\
\text { intelligence }\end{array}$ & $\begin{array}{l}\text { Correlation } \\
\text { coefficient }\end{array}$ & 1.00 & $0.49^{* *}$ & $0.36^{* *}$ \\
& $\begin{array}{l}\text { Sig. (2-tailed) } \\
\text { Leadership }\end{array}$ & - & 0.00 & 0.00 \\
& $N$ & 107 & 107 & 107 \\
& $\begin{array}{l}\text { Correlation } \\
\text { coefficient }\end{array}$ & $0.49^{* *}$ & 1.00 & $0.34^{* *}$ \\
& Sig. (2-tailed) & 0.00 & - & \\
& $N$ & 107 & 107 & 0.00 \\
Self-efficacy & $\begin{array}{l}\text { Correlation } \\
\text { coefficient }\end{array}$ & $0.36^{* *}$ & $0.34^{* *}$ & 107 \\
& Sig. (2-tailed) & 0.00 & 0.00 & - \\
& $N$ & 107 & 107 & 107 \\
\hline
\end{tabular}

**, Correlation is significant (Sig.) at the 0.01 level (2-tailed).

TABLE 7: Shapiro-Wilk's test of normality for subscales.

\begin{tabular}{llll}
\hline Subscale & $\begin{array}{l}\text { Shapiro-Wilk } \\
\text { statistics }\end{array}$ & $\boldsymbol{d f}$ & $\boldsymbol{p}$-value \\
\hline Emotions subscale 1 & 0.98 & 107 & 0.10 \\
\hline Emotions subscale 2 & 0.94 & 107 & 0.00 \\
\hline Emotions subscale 3 & 0.95 & 107 & 0.00 \\
\hline Emotions subscale 4 & 0.89 & 107 & 0.00 \\
\hline Leadership subscale 1 & 0.87 & 107 & 0.00 \\
\hline Leadership subscale 2 & 0.93 & 107 & 0.00 \\
\hline Leadership subscale 3 & 0.89 & 107 & 0.00 \\
\hline Leadership subscale 4 & 0.95 & 107 & 0.00 \\
\hline Leadership subscale 5 & 0.91 & 107 & 0.00 \\
\hline Leadership subscale 6 & 0.92 & 107 & 0.00 \\
Leadership subscale 7 & 0.97 & 107 & 0.03 \\
Leadership subscale 8 & 0.94 & 107 & 0.00 \\
Leadership subscale 9 & 0.83 & 107 & 0.00 \\
Leadership subscale 10 & 0.91 & 107 & 0.00 \\
Leadership subscale 11 & 0.87 & 107 & 0.00 \\
\hline Leadership subscale 12 & 0.93 & 107 & 0.00 \\
Self-efficacy & 0.92 & 107 & 0.00 \\
\hline Leadership & 0.96 & 107 & 0.00 \\
\hline Emotional intelligence & 0.98 & 107 & 0.13 \\
\hline
\end{tabular}

$d f$, degrees of freedom.

Inspirational motivation was moderately correlated with managing others' emotions $(r=0.458 ; p<0.01)$, and the management by expectation (passive) and laissez-faire subscales were negatively correlated with the managing others' emotions subscale $(p>0.05)$.

The management by exception (active) leadership subscale had a significant correlation with the utilising emotions subscale $(r=0.323 ; p<0.01)$. However, the rest of the leadership subscales with significant correlations were modestly correlated with utilising emotions. The researcher therefore inferred that utilising emotions, which is the ability to identify emotions and also indicates the ability to accurately perceive, appraise and express emotions (Weisinger, 1998), 
TABLE 8: Correlations between the self-efficacy scale and the subscales of Assessing Emotions Scale and the Multifactor Leadership Questionnaire.

\begin{tabular}{|c|c|c|c|c|c|c|}
\hline \multirow[t]{2}{*}{ Leadership subscales } & \multirow{2}{*}{$\begin{array}{l}\text { Correlation } \\
\text { applications }\end{array}$} & \multicolumn{5}{|c|}{ Assessing emotions subscales } \\
\hline & & $\begin{array}{l}\text { Perception of emotions } \\
\qquad(\alpha=0.73)\end{array}$ & $\begin{array}{c}\text { Managing own } \\
\text { emotions }(\alpha=0.72)\end{array}$ & $\begin{array}{l}\text { Managing others' } \\
\text { emotions }(\alpha=0.67)\end{array}$ & $\begin{array}{l}\text { Utilising emotions } \\
\qquad(\alpha=0.74)\end{array}$ & $\begin{array}{c}\text { Self-Efficacy } \\
(\alpha=0.83)\end{array}$ \\
\hline \multirow{3}{*}{$\begin{array}{l}\text { Idealised influence } \\
\text { (Attributes; } \alpha=0.793 \text { ) }\end{array}$} & Correlation coefficient & $0.35 * *$ & $0.40^{* *}$ & $0.37^{* *}$ & $0.22 *$ & $0.34^{* *}$ \\
\hline & Sig. (2-tailed) & 0.00 & 0.00 & 0.00 & 0.02 & 0.00 \\
\hline & $N$ & 107 & 107 & 107 & 107 & 107 \\
\hline \multirow{3}{*}{$\begin{array}{l}\text { Idealised influence } \\
\text { (Behaviour; } \alpha=0.744 \text { ) }\end{array}$} & Correlation coefficient & $0.39 * *$ & $0.38^{* *}$ & $0.41^{* *}$ & $0.20 *$ & $0.46^{* *}$ \\
\hline & Sig. (2-tailed) & 0.00 & 0.00 & 0.00 & 0.03 & 0.00 \\
\hline & $N$ & 107 & 107 & 107 & 107 & 107 \\
\hline \multirow{3}{*}{$\begin{array}{l}\text { Inspirational motivation } \\
(\alpha=0.692)\end{array}$} & Correlation coefficient & $0.22 *$ & $0.46^{* *}$ & $0.45^{* *}$ & 0.17 & $0.34 * *$ \\
\hline & Sig. (2-tailed) & 0.02 & 0.00 & 0.00 & 0.06 & 0.00 \\
\hline & $N$ & 107 & 107 & 107 & 107 & 107 \\
\hline \multirow{3}{*}{$\begin{array}{l}\text { Intellectual stimulation } \\
(\alpha=0.538)\end{array}$} & Correlation coefficient & $0.39 * *$ & $0.40 * *$ & $0.30 * *$ & 0.13 & $0.41^{* *}$ \\
\hline & Sig. (2-tailed) & 0.00 & 0.00 & 0.00 & 0.16 & 0.00 \\
\hline & $N$ & 107 & 107 & 107 & 107 & 107 \\
\hline \multirow{2}{*}{$\begin{array}{l}\text { Individualised consideration } \\
(\alpha=0.604)\end{array}$} & Sig. (2-tailed) & 0.00 & 0.00 & 0.01 & 0.00 & 0.00 \\
\hline & $N$ & 107 & 107 & 107 & 107 & 107 \\
\hline \multirow{3}{*}{$\begin{array}{l}\text { Constructive transaction } \\
(\alpha=0.705)\end{array}$} & Correlation coefficient & $0.37^{* *}$ & $0.43^{* *}$ & $0.28 * *$ & $0.24 *$ & $0.37 * *$ \\
\hline & Sig. (2-tailed) & 0.00 & 0.00 & 0.00 & 0.01 & 0.00 \\
\hline & $N$ & 107 & 107 & 107 & 107 & 107 \\
\hline \multirow{3}{*}{$\begin{array}{l}\text { Management by exception } \\
\text { (Active; } \alpha=0.565 \text { ) }\end{array}$} & Correlation coefficient & $0.36^{* *}$ & $0.19 *$ & $0.23 *$ & $0.32 * *$ & 0.18 \\
\hline & Sig. (2-tailed) & 0.00 & 0.05 & 0.01 & 0.00 & 0.05 \\
\hline & $N$ & 107 & 107 & 107 & 107 & 107 \\
\hline \multirow{3}{*}{$\begin{array}{l}\text { Management by exception } \\
\text { (Passive; } \alpha=0.486 \text { ) }\end{array}$} & Correlation coefficient & -0.03 & -0.09 & -0.04 & 0.10 & $-0.22^{*}$ \\
\hline & Sig. (2-tailed) & 0.76 & 0.34 & 0.61 & 0.29 & 0.02 \\
\hline & $N$ & 107 & 107 & 107 & 107 & 107 \\
\hline \multirow[t]{3}{*}{ Laissez-faire $(\alpha=0.550)$} & Correlation coefficient & $-0.25 * *$ & -.016 & -0.07 & 0.03 & $-0.52 * *$ \\
\hline & Sig. (2-tailed) & 0.00 & 0.08 & 0.42 & 0.71 & 0.00 \\
\hline & $N$ & 107 & 107 & 107 & 107 & 107 \\
\hline Extra effort $(\alpha=0.628)$ & $N$ & 107 & 107 & 107 & 107 & 107 \\
\hline \multirow[t]{3}{*}{ Effectiveness ( $\alpha=0.702$ ) } & Correlation coefficient & $0.29 * *$ & $0.44 * *$ & $0.27^{* *}$ & $0.21 *$ & $0.48^{* *}$ \\
\hline & Sig. (2-tailed) & 0.00 & 0.00 & 0.00 & 0.02 & 0.00 \\
\hline & $N$ & 107 & 107 & 107 & 107 & 107 \\
\hline \multirow[t]{3}{*}{ Satisfaction ( $\alpha=0.461)$} & Correlation coefficient & 0.08 & $0.39 * *$ & $0.34^{* *}$ & $0.20^{*}$ & 0.09 \\
\hline & Sig. (2-tailed) & 0.36 & .00 & .00 & .036 & 0.35 \\
\hline & $N$ & 107 & 107 & 107 & 107 & 107 \\
\hline \multirow[t]{4}{*}{ Self-efficacy scale ( $\alpha=.833$ ) } & Correlation coefficient & $0.43^{* *}$ & $0.33^{* *}$ & 0.165 & 0.17 & - \\
\hline & - & 0.00 & 0.00 & 0.090 & 0.07 & - \\
\hline & Sig. (2-tailed) & - & 107 & 107 & 107 & - \\
\hline & $N$ & 107 & - & - & - & - \\
\hline
\end{tabular}

${ }^{* *}$, Correlation is significant (Sig.) at the 0.01 level (2-tailed)

had minimal impact on leadership, including leadership effectiveness.

A trend in Table 8 reveals that self-efficacy and the assessingemotions subscales had a negative to poor correlation with management by exception (passive) and laissez-faire. One can therefore infer that, as emotional intelligence and selfefficacy increase, laissez-faire and management by exception will decrease. Laissez-faire and management by exception (passive) are considered to be ineffective leadership styles, which means that one can further conclude that, should emotional intelligence and self-efficacy increase, leadership effectiveness will increase.

Self-efficacy had a significant correlation with the effectiveness subscale $(r=0.484 ; p<0.01)$. This result supports
Hypothesis 2 of this research study, which states that there is a statistically positive relationship between self-efficacy and leadership effectiveness. This is further supported with self-efficacy being moderately correlated with the leadership subscales, namely idealised influence (active and passive), inspirational motivation, intellectual stimulation and individual consideration, which are considered effective leadership behaviour.

Self-efficacy was also moderately correlated with perception of emotions $(r=0.436 ; p<0.01)$ and managing own emotions $(r=0.331 ; p<0.01)$ whilst being modestly correlated with managing own emotions $(r=0.165 ; p<0.01)$ and utilising emotions $(r=0.172 ; p<0.01)$. In managing own emotions, the respondent is expected to indicate how effective each action would be to cope with emotions in a situation in which 
he or she is involved (Mayer \& Salovey, 1997) whilst Bandura (1997) states that self-efficacy is the belief in one's capabilities to organise and execute the course of action required to produce given attainments. The common thread between managing own emotions and self-efficacy is the awareness of being able to control one's capabilities to effectively deal with a given situation or, in this instance, emotions. This correlation result supports Hypothesis 3 of this research study, namely that there is a statistically positive relationship between emotional intelligence and self-efficacy.

Table 8 provides an array of statistical data concerning the instruments that were used in this research study. Although Table 6 rejects three of the null hypotheses and favours the corresponding alternate hypothesis, Table 8 provides a detailed understanding of the relationship between subscales, which may not have been portrayed in Table 6 .

\section{Discussion}

The aim of this research study was to gain a better understanding of the relationship between emotional intelligence and self-efficacy as attributes and the extent (if any) to which they influence leadership effectiveness. The overall results of the study support the proposition that emotional intelligence and self-efficacy as attributes do influence leadership effectiveness.

In this study, it was assumed that emotional intelligence is correlated with leadership effectiveness. This hypothesis was confirmed by the statistical analysis which indicated that emotional intelligence is positively correlated with leadership effectiveness. According to George (2000), emotional intelligence plays a key role in leadership effectiveness and can promote effectiveness at all levels in organisations. Effective leaders with high emotional intelligence could help the people they lead to raise their own level of emotional intelligence, potentially resulting in a more effective organisation overall and a better organisational climate (Momeni, 2009). As indicated in the results, the managing own emotions subscale was significantly correlated with the effectiveness outcome on the leadership subscale. This supports the assumption that leadership effectiveness may have its roots in managing emotions (Caruso, Mayer \& Salovey, 2002).

A study by Coetzee and Schaap (2005) indicated a significant correlation between the emotional-intelligence scores and the effective- and ineffective-leadership scores $(r=0.342$; $p<0.01)$ of the sample group. In this study, leadership effectiveness was also significantly positively related $(t=2.359 ; p<0.05)$ to emotional intelligence, and ineffective leadership was significantly negatively related $(t=-2.645$; $p<0.01)$ to emotional intelligence. Furthermore, three of the four emotional-intelligence subscales had a negative correlation with the laissez-faire and management by exception (passive) leadership subscale, and the fourth was poorly correlated. Laissez-faire behaviour is characterised by a general failure to take responsibility for managing (Eagly et al., 2003) and considered least effective, followed by management by exception in terms of leadership effectiveness (Coetzee \& Schaap, 2005).

This research study was also interested in establishing whether or not a relationship exists between self-efficacy and effective leadership. The findings suggest a significant relationship between self-efficacy and effective leadership. However, there were negative correlations between selfefficacy and certain leadership subscales. On the basis of the theory of self-efficacy (Bandura, 1997), one would expect leaders with greater self-efficacy to be more effective because they are inclined to expend greater efforts to fulfil their leadership roles and to persevere for longer when faced with difficulties ( $\mathrm{Ng}$, Ang \& Chan, 2008). The result of this research study supports the assumption made by $\mathrm{Ng}$ et al. (2008). Self-efficacy was negatively correlated with laissezfaire and management by exception (passive). According to Felfe and Schyns (2002), management by exception (passive) and laissez-faire, which are both contained in the MLQ, are forms of ineffective leadership. One could therefore infer that as self-efficacy increases, leadership effectiveness increases. It should be noted that there are limited studies on leadership effectiveness and self-efficacy, but there are studies in the academic fraternity that explore leadership effectiveness and leadership self-efficacy. Self-efficacy and leader self-efficacy have the same foundational value but are defined as different constructs. Bandura (1997, p. 3) defines self-efficacy as the beliefs in ones capabilities to organise and execute the courses of action required to produce given attainments'. However, the definition of leadership self-efficacy is referred to as one's self-perceived capabilities to perform the cognitive and behavioural functions necessary to regulate group process in relation to goal achievement (McCormick, 2001).

Another aim of this study was to determine whether or not a relationship exists between emotional intelligence and selfefficacy. The results indicate that a significant relationship between emotional intelligence and self-efficacy does in fact exist. Self-efficacy was moderately correlated with the subscale perception of emotions. This supports the research by Schutte et al. (2009), which indicates that self-efficacy for emotional functioning is the perception or belief that one can achieve the desired outcomes in the emotional realm.

\section{Limitations of the study}

This research was not without its limitations. The first limitation relates to the nature of the sample. The sample size was small, $n=107$. The sample can also be considered to be gender and age biased, that is, there were more males than females in the sample, and the age category indicated that most of the sample participants were between the ages of 39 and 49. The second limitation relates to the reliability coefficient for the subscales of the MLQ, which were significantly lower than the full-scale reliability. Factor analysis could not validate the subscales used in the correlation analysis, which was also a limitation to the study. The use of the Spearman coefficient, however, does not necessarily mean cause and 
effect. In similar studies, more advanced inferential statistics methods such as multiple regression analysis or structural equation modelling could be employed to also determine cause-and-effect relationships.

Lastly, it should be noted that the results are specific to the police context and cannot be generalised to other populations.

\section{Recommendations}

Recommendations are made for future research and for the organisation.

\section{Future research}

On the basis of the findings of this research study, the following recommendations are made for future research:

- Future studies aimed at improving on this research study could include a larger sample size and a sample population that represents police commanders from different parts of South Africa.

- Another approach to this study could look at research in terms of biographical dynamics such as race, gender, age and region and its influence.

- Other research could investigate leadership styles and the impact they have on leadership effectiveness. Further investigation could report on the current police leadership style and what leadership style would generate effective leaders, taking into consideration the nature of the work.

- More advanced inferential statistics methods such as multiple regression analysis or structural equation modelling could be employed in future studies to also determine cause-and-effect relationships.

\section{Recommendations for the organisation}

On the basis of the findings in this research study, the following recommendations are made for the organisation:

- Owing to the complexity and nature of work in police organisations, leaders face different challenges from those in other environments. Hence a way to equip these leaders would be through offering developmental programmes for current leaders.

- Furthermore, potential leaders have to be initiated into these developmental programmes to better prepare them for leadership in the police and to foster effective leadership. It would thus be useful for the police organisation to create a talent-management strategy, focusing on identification of potential leaders and succession planning.

- The current recruitment and selection policy in the organisation could be revised to address the implementation of selection instruments that screen for psychological constructs like emotional intelligence and self-efficacy which impact on leadership of policing organisations.

- As identified in this study, the number of females in commanding positions is significantly lower than the number of males. The organisation could thus revise its strategy for addressing transformational change by placing more females in commanding positions.

\section{Conclusion}

The objective of this research study was to determine the relationship between emotional intelligence and selfefficacy as attributes of leadership effectiveness in a police organisation. The key variables of emotional intelligence, self-efficacy and leadership effectiveness were discussed in the literature.

The three hypotheses in this study were confirmed by the statistical analysis. There is a significant correlation between emotional intelligence and effective leadership, there is a significant correlation between self-efficacy and effective leadership, and lastly, there is a significant correlation between emotional intelligence and self-efficacy. It should be noted that, owing to a deviation in normality, a nonparametric correlation analysis was used to test the abovementioned hypotheses.

In conclusion, the intention of conducting this research was to create awareness of how certain psychological constructs as attributes may influence leadership effectiveness. According to Herbst and Maree (2008), the role that attributes play in predicting leadership success will become more prominent as leadership situations become more complex, and varied leadership represents a crucial determinant of police organisational efficacy (Adam, 2010). Police organisations need to formulate definitions of what effective leadership means in their own communities and policing contexts (Schafer, 2008). This study indicated that there are positive correlations between the constructs emotional intelligence, self-efficacy and leadership effectiveness. Hence emotional intelligence and self-efficacy as attributes do play a role in leadership effectiveness.

\section{Acknowledgements Competing interests}

The authors declare that they have no financial or personal relationship(s) that may have inappropriately influenced them when they wrote this article.

\section{Authors' contributions}

N.M (University of South Africa) was the promoter of Y.R. (University of South Africa) for her master's dissertation. The article flows from her research in this regard.

\section{References}

Adam, T.B. (2010). A conceptual framework for leadership development in the South African Police Service based on transformational learning theory. Unpublished master's thesis, Stellenbosch, University of Stellenbosch, South Africa.

Bandura, A. (1986). Social foundations of thought and action: Asocial cognitive theory. Englewood Cliffs, NJ: Prentice-Hall.

Bandura, A. (1997). Self-efficacy: The exercise of self-control. New York: Freeman.

Barling, J., Slater, F., \& Kelloway, E.K. (2000). Transformational leadership and emotional intelligence: An exploratory study. Journal of Leadership and Organization Development, 21(1), 157-161. http://dx.doi.org/10.1108/01437730010325040

Bass, B.M., \& Avolio, B.J. (1994). Improving organizational effectiveness through transformational leadership. Thousand Oaks, CA: Sage.

Bipath, M. (2007). The dynamic effects of leader emotional intelligence and organisational culture on organisational performance. Doctoral dissertation. Pretoria: University of South Africa. 
Campbell, I., \& Kods, L. (2011).What makes great police leadership? A rapid evidence review. Research, Analysis and Information, June, 2-27.

Caruso, D.R., Mayer, J.D., \& Salovey, P. (2002). Relation of an ability measure of emotional intelligence to personality. Journal of Personality Assessment, 79(2) 306-320. http://dx.doi.org/10.1207/S15327752JPA7902_12

Cavazotte, F., Moreno, V., \& Hickmann, M. (2012). Effects of leader intelligence, personality and emotional intelligence on transformational leadership and managerial performance. The Leadership Quarterly, 23(3), 443-455. http:// dx.doi.org/10.1016/j.leaqua.2011.10.003

Clark, M. (2005).The importance of new philosophy to the post-modern policing environment. Policing: An International Journal of Police Strategies and Management, 28(4), 642-653. http://dx.doi.org/10.1108/13639510510628721

Cohen, L., Manion, L., \& Morrison, K. (2007). Research methods in education. (6th edn.). New York: Routledge.

Coetzee, M., \& Beukes, C.J. (2010). Employability, emotional intelligence and caree preparation support satisfaction among adolescents in the school-to-work preparation support satisfaction among adolescents in the
transition phase. Journal of Psychology in Africa, 20(3), 439-446.

Coetzee, C., \& Schaap, P. (2005).The relationship between leadership behaviour outcomes of leadership and emotional intelligences. South African Journal of Industrial Psychology, 31(3), 31-38.

Chuang, A., Judge, T.A., \& Liaw, Y.J. (2012). Transformational leadership and customer service: A moderated mediation model of negative affectivity and emotion regulation. European Journal of Work and Organizational Psychology, 21(1), 2856. http://dx.doi.org/10.1080/1359432X.2010.532911

De Miranda, L.C.S. (2011). The relationship between emotional intelligence and leadership effectiveness with an emphasis on corporate culture in a consumer goods organisation. Master's thesis, University of South Africa: Pretoria.

Dorbrzanska, A. (2005). ACA leadership development training: Becoming the effective leaders of tomorrow. Corrections Today, 67(6), 22-34.

Eagly, A.H., Schmidt, M.C., \& Van Engen, M.L. (2003). Transformational, transactional, and laissez-faire leadership styles: A meta-analysis comparing women and men. American Psychological Association, 129(4), 569-591.

Eden, D. (1988). Pygmalion, goal-setting and expectancy: Compatible ways to raise productivity. Academy of Management Review, 13, 652-666. http://dx.doi. productivity. Academy of Mana
org/10.5465/AMR.1988.4307530

Felfe, J., \& Schyns, B. (2002).The relationship between employees' occupational selfefficacy and perceived transformational leadership-replication and extension of recent results. Current Research in Social Psychology, 7(9), 137-162.

Field, A. (2009). Discovering statistics using SPSS. (3rd edn.). London: SAGE.

Furlong, N., Lovelace, E., \& Lovelace, K. (2000). Research methods and statistics: An integrated approach. Orlando, FL: Harcourt Brace.

Gardner, D.G., \& Pierce, J.L. (1998). Self-esteem and self-efficacy within the organisational context. Group and Management, 23(1), 48-70. http://dx.doi. org/10.1177/1059601198231004

George, J.M. (2000). Emotions and leadership: The role of El. Human Relations, 53(12), 1027-1041. http://dx.doi.org/10.1177/0018726700538001

Goleman, D. (1998). Working with emotional intelligence. New York: Bantam.

Gilley, A., McMillan, S.H., \& Gilley, J.W. (2009). Organisational change and characteristics of leadership effectiveness. Journal of Leadership and Organizational Studies, 16(1), 38-47. http://dx.doi.org/10.1177/1548051809334191

Hayward, B.A. (2005). Relationship between employee performances, leadership and emotional intelligence in a South African parastatal organisation. Master's thesis. Cape Town: Rhodes University.

Heifetz, R.A., \& Linsky, M. (2004).A survival guide for leaders. Harvard Business Review, 80(6), 65-73.

Herbst, T.H., \& Maree, K.G. (2008).Thinking-style preference, emotional intelligence and leadership effectiveness. South African Journal of Industrial Psychology, 34(1), 32-41.

Higgs, M.J., \& Dulewicz, V. (1999). Making sense of emotional intelligence. Windsor: NFER-Nelson.

Hogan, R., Curphy, G.J., \& Hogan, J. (1994). What we know about leadership: Effectiveness and personality. American Psychologist, 49(6), 493-526. http:// dx.doi.org/10.1037/0003-066X.49.6.493

Hollander, E.P. (1978). Leadership dynamics: A practical guide to effective relationships. New York: The Free Press.
Howard, W.C. (2005). Leadership: Four styles. Education Resource Information Centre, 126(2), 384-391.

Hughes, R.L., Ginnett, R.C., \& Curphy, G.J. (2006).Leadership enhancing the lessons of experience. New York: McGraw-Hill.

Humphrey, R. (2002). The many faces of emotional leadership. The Leadership Quarterly, 13(5), 493-504. http://dx.doi.org/10.1016/S1048-9843(02)00140-6

Judge, T.A., Locke, E.A., Durham, C.C., \& Kluger, A.N. (1998). Dispositional effects on job and life satisfaction: the role of core evaluations. Journal of Applied Psychology, 83, 17-34. http://dx.doi.org/10.1037/0021-9010.83.1.17

Kellett, J.B., Humphrey, R.H., \& Sleeth, R.G. (2002).Empathy and complex task performance: Two routes to leadership. Leadership Quarterly, 13, 523-544. http://dx.doi.org/10.1016/S1048-9843(02)00142-X

Lewis, P.S., Goodman, S.H., \& Fandt, P.M. (1998). Management: Challenges in the 21st century. Cincinnati, $\mathrm{OH}$ : Thomson.

Mattes, R. (2006). How does SA compare? Experiences of crime and policing in an African context. South African Crime Quarterly, 18, 17-24.

Marais, C.P. (1997). Salutogenesis as a paradigm in change management. Master's dissertation, University of South Africa, Pretoria.

Mayer, J.D., \& Salovey, P. (1997). What is emotional intelligence?. In P. Salovey, \& D. Sluyter (Eds.), Emotional development and emotional intelligence: Implications for educators (pp. 3-31). New York: Basic Books.

Mayer, J.D., Salovey, P., \& Caruso, D. (2000). Emotional intelligence meets traditiona standards for an intelligence. Intelligence, 27(4), 267-298. http://dx.doi. org/10.1016/S0160-2896(99)00016-1

McCormick, M.J. (2001). Self-efficacy and leadership effectiveness: Applying socia cognitive theory to leadership. Journal of Leadership and Organisational Studies, 8(22), 22-23. http://dx.doi.org/10.1177/107179190100800102

Momeni, N. (2009). The relation between managers' emotional intelligence and the organizational climate they create. Public Personnel Management, 38(2), 35-48.

Oosthuizen, R.M. (1998). Brandweermanne in 'n plaaslike owerheid se hantering van stres: ' $n$ Fortigene benadering. Master's dissertation, North-West University, Mmabatho.

Palis, L.L., \& Green, S.G. (2001). Leadership self-efficacy and managers motivation for leading change. Journal of Organizational Behavior, 23, 215-235. http://dx.doi org/10.1002/job.137

Palmer, B., Walls, M., Burgess, M., \& Stough, C. (2001). Emotional intelligence and effective leadership. Journal of Leadership and Organization Development, 22(1), 5-10. http://dx.doi.org/10.1108/01437730110380174

Pett, M.A. (1997). Non-parametric statistics for health care research: Statistics for small samples and unusual distributions. London: Sage.

Pillay, M., Viviers, R., \& Mayer, C. (2013). The relationship between emotional intelligence and leadership styles in the South African petrochemical industry. $S A$ Journal of Industrial Psychology/SA Tydskrif vir Bedryfsielkunde, 39(1), Art. \#1109, 12 pages. http://dx.doi.org/10.4102/ sajip.v39i1.1109

Riggio, R.E., Murphy, S.E., \& Pirozzolo, F.J. (2002).Multiple intelligences and leadership. Mahwah, NJ: Lawrence Erlbaum Associates.

Schafer, J.A. (2008). Developing effective leadership in policing: Perils, pitfalls and paths forward. Policing: An international Journal of Police Strategies and Management, 32(2), 238-260.

Sherer, M., Maddux, J.E., Mercandante, B., Prentice-Dunn, S., Jacobs, B., \& Rogers, R.W. (1982). The self-efficacy scale: Construction and validation. Psychologica Reports, 51, 633-671. http://dx.doi.org/10.2466/pr0.1982.51.2.663

Terre Blanche, M., Durrheim, K., \& Painter, D. (Eds.) (2006). Research in practice Applied methods for the social sciences. (2nd edn.). Cape Town: University of Cape Town Press.

Villanueva, J.J., \& Sanchez, J.C. (2007). Trait emotional intelligence and leadership self-efficacy: Their relationship with collective efficacy. The Spanish Journal of Psychology, 10(2), 349-357. http://dx.doi.org/10.1017/S1138741600006612

Weinberger, L.A. (2004). An examination of the relationship between emotiona intelligence and leadership style. Minnesota: University of Minnesota.

Weisinger, H. (1998). Emotional intelligence at work. San Francisco, CA: Jossey-Bass.

Wolff, S.B., Pescosolido, A.T., \& Druskat, V.U. (2002). Emotional intelligence as the basis of leadership emergence in self-managing teams. Leadership quarterly, 13 505-522. http://dx.doi.org/10.1016/S1048-9843(02)00141-8

Yukl, G.A. (1981). Leadership in organisations. Englewood Cliffs, NJ: Prentice-Hall. 